Article

\title{
Evolution of Integrated Open Aquaculture Systems in Hungary: Results from a Case Study
}

\author{
József Popp ${ }^{1}$, László Váradi ${ }^{2}$, Emese Békefi ${ }^{3}$, András Péteri ${ }^{3}$, Gergó Gyalog ${ }^{3}$, Zoltán Lakner ${ }^{4}$ \\ and Judit Oláh $5, *$ \\ 1 Faculty of Economics and Business, Institute of Sectoral Economics and Methodology, \\ University of Debrecen, 4032 Debrecen, Hungary; popp.jozsef@econ.unideb.hu \\ 2 Hungarian Aquaculture and Fisheries Inter-Branch Organisation (MA-HAL), Ballagi Mór u. 8, \\ 1118 Budapest, Hungary; varadil@akvapark.hu \\ 3 Research Institute for Fisheries and Aquaculture (NARIC HAKI), National Agricultural Research and \\ Innovation Centre, 8 Anna-liget, 5540 Szarvas, Hungary; bekefi.emese@haki.naik.hu (E.B.); \\ shubunkin@invitel.hu (A.P.); gyalog.gergo@haki.naik.hu (G.G.) \\ 4 Szent István University, Faculty of Food Science, 1118 Budapest, Hungary; lakner.zoltan@szie.hu \\ 5 Faculty of Economics and Business, Institute of Applied Informatics and Logistics, University of Debrecen, \\ 4032 Debrecen, Hungary \\ * Correspondence: olah.judit@econ.unideb.hu; Tel.: +36-202-869-085
}

Received: 20 December 2017; Accepted: 9 January 2018; Published: 12 January 2018

\begin{abstract}
This article presents the history of integrated farming in aquaculture through a Hungarian case study. The development of Hungarian integrated aquaculture is aligned with global trends. In the previous millennium, the utilization of the nutrients introduced into the system was the main aspect of the integration. In Hungary, technologies that integrated fish production with growing crops and animal husbandry appeared, including for example: large-scale fish-cum-rice production; fish-cum-duck production; and integrated pig-fish farming which were introduced in the second half of the 20th century. Today, the emphasis is on integrating the use of the kind of feed where the main goal is to minimize nutrient loads in the surrounding natural ecosystems and to maximize the utilization of the unit's water resources. The various modern integrated freshwater aquaculture systems, such as intensive fish production combined with wetland, recirculation aquaculture system and multi-functional aquaculture, have proved their viability. However, the future opportunities for these systems have not always been properly recognized and acknowledged when the future of European aquaculture is discussed.
\end{abstract}

Keywords: integrated multi-trophic aquaculture; ecological aquaculture; environmentally sustainable aquaculture; sustainable production; challenges

\section{Introduction}

According to the Organisation for Economic Co-operation and Development/Food and Agriculture Organization of the United Nations (OECD/FAO), global fish production (capture and aquaculture) increased by $24 \%$ between 2006 and 2015 and reached 167 million tonnes on average over 2013-2015. The share of total fish production for human consumption was around $88 \%$, or 147 million tonnes, and aquaculture represented about $50 \%$ of the fish consumed. Further expansion in fish consumption will mainly derive from aquaculture production; however, the average annual growth rate of aquaculture will slow down from $5.4 \%$ per annum in the previous decade to $3.0 \%$ per annum in the period between 2015 and 2025. In 2025, fish originating from aquaculture is expected to represent $57 \%$ of the fish consumed [1,2].

Aquaculture has great potential to expand and intensify sustainably in order to meet the demand for fish in 2050, as the human population is predicted to continue to grow for the next 40 years before 
stabilizing at a minimum of 9 billion people [3]. It is a general tendency across agricultural systems that farming technologies have been intensified to meet the increasing demand for food. Since the millennium, the expansion in fish production has originated from intensification of production technologies, which is characterized by a tendency towards specialized aquaculture farms and monocultured fish stock. Integrated rearing of target fish species with other fish species, terrestrial animals, or crops, has not been at the forefront of global aquaculture development in the last few years.

The practice of livestock/fish integration, which was flourishing some decades ago [4-6], is in decline as livestock farms are increasingly run as separate, highly specialized enterprises. In most cases the ready availability and low cost of industrial nutrients has reduced the need for integrating crop and livestock production. Concerns about bio-security in order to minimize the risks of animal and human diseases also preclude integration of large-scale livestock with pond aquaculture [4].

A few decades ago in pond aquaculture-which accounts for a large part of global aquaculture-it was typical to grow herbivorous and omnivorous species in a polyculture. Nowadays, technical improvement and economies of scale characteristic of industrial technologies encourage the shift toward monoculture of target aquaculture species [5].

Traditionally, in integrated agriculture-aquaculture systems and in polyculture farming, the most typical nutrient inputs were production wastes, by-products, manure and natural food for most farmed aquatic organisms [4]. Recently it has become a global trend that even herbivorous and omnivorous species that are traditionally considered to be relatively low-input species such as carp are increasingly being fed on compound feed [6]. The main economic driver behind pellet-based intensification was that land and water costs increased at a higher rate than the cost of feed ingredients: yields had to be increased so that increased fixed costs are spread out over a larger production [7]. Moreover, technological advances in feeding and feed formulations, in water treatment, and in water chemistry, have led to higher production intensity and specialization and have also contributed to this progress. The increasing use of pelleted feed in modern aquaculture has led to major environmental concerns [6]. Integrated and polyculture systems ensured the maximum utilization of all resources, such as land, water and feed, and also minimized waste. As industrial monoculture has evolved to supply ever larger, more concentrated markets with homogenous products [4], it has posed a challenge to the need to foster environmental sustainability in aquaculture, because specialized aquaculture farms with pellet fed monoculture stocks are not currently environmentally sustainable compared to the previous integrated/polyculture/natural nutrition and circular economy systems. New forms of integration of different activities have to be sought to minimize discharges. At the same time, the principle that the organic waste of one aquaculture system can be the input for another aquaculture system (the blue economy) is today more important than ever before. Based on this principle, modern methods and techniques can be used to operate freshwater aquaculture systems that will find target markets for the fish they produce in spite of the fact that mariculture offers great hope for the future. For this reason, it is time to rethink the future of integrated nutrient utilization by presenting case studies from Hungary of various integrated freshwater aquaculture systems in Section 3.

The term integrated multi-trophic aquaculture (IMTA) encompasses various concepts. The term multi-trophic refers to the incorporation of species from different trophic or nutritional levels in the same system, and this is one potential distinction from polyculture systems. The integrated in IMTA refers to the more intensive cultivation of the different species in proximity to each other, connected by nutrient and energy transfer through water [8]. The principle of IMTA is the co-cultivation of fed fish with organic and inorganic extractive species [9-11]. IMTA has been proposed for mitigating aquaculture waste release [12], as well as the advantages it offers, including a reduced ecological footprint, economic diversification and the increased social acceptability of culturing systems. These systems are defined by [13] as cultures that use species from different trophic levels grown in combination within the same water body or through some other water-based linkage (for land-based systems). In a perfect IMTA system the processing of biological and chemical wastes by other species would make the whole production cycle environmentally neutral [14]. Thus, the principles of IMTA 
aim to create a circular economy that minimizes energy flows, losses and environmental deterioration, without restricting economic growth or social progress [15]. The concept of IMTA is to create balanced systems for environmental sustainability, economic viability, and social acceptability [16].

Due to positive environmental externalities, the social benefits associated with IMTA are greater than the private benefits. This implies that there is a role for the government to generalize IMTA to achieve more total benefits. However, while single policies, such as subsidies, may backfire, a combination of policies designed to promote IMTA could be effective [17]. A working IMTA system can result in greater total production based on mutual benefits for the co-cultured species and improved ecosystem health, even if the production of individual species is lower than in a monoculture over a short term period [18-20]. Mathematical models have been applied to predict yield [21,22], environmental effects [23,24], and economic optimization [25] of finfish and bivalve monoculture [16]. A larger US public survey study (4653 respondents) found that consumers were supportive of more sustainable aquaculture production systems and willing to pay a price premium for IMTA products; however, there is a need for clear marketing communication to differentiate the products of IMTA from those of monocultures [26].

In the context of freshwater aquaculture, the term freshwater integrated multi-trophic aquaculture (FIMTA) was developed by [27-29], and this term usually refers to aquaponics systems as a combination of tank aquaculture operation with plant hydroponic cultivation. In this paper, we have attempted to outline the evolution of integrated open freshwater aquaculture systems that are the combinations of pond aquaculture systems sharing resources with other activities. Integrated pond aquaculture as a global practice is described by [30], however, we focus on the European applications by reporting results from a case study in Hungary.

\section{Case Study: Integrated Freshwater Aquaculture in Hungary}

The integration of fish culture and other agricultural activities has always played an important role in the pond fish production of Hungary. Organic manuring, a basic method of increasing the natural yield, did not only mean transporting the manure from an animal farm to the fish pond and adding it to the water, but integrating the pond-fish production with livestock and/or crop production. Classical examples are fish-cum-duck farming, introducing the liquid manure from a pig farm located next to the pond into the water, or fish production on rice paddies. The application of integrated technologies allowed the production of organisms belonging to different trophic levels (e.g., algae, aquatic plants, zooplankton, water insects, fish, ducks, pigs) within one farm or even one territorial unit; most of them, directly or indirectly, intended for human consumption. While the concept of IMTA, or even that of aquaculture, was unknown in the golden era of integrated pond fish farming, in fact, most of these fishpond-based integrated systems were already integrated in multitrophic aquaculture systems. Of course, the functional relationships between the different trophic levels were not yet fully explored and well-regulated, yet these systems contributed to the sustainable use of natural resources and the protection of the natural environment through the utilization of organic waste or a better use of production areas. The expansion of knowledge and technological development has brought significant changes in the traditional integrated fishpond systems. The modern IMTA systems, in which fishponds are still a principal component, contribute to sustainable intensification, i.e., allow the production of more food per unit of area, without increasing the negative environmental impact or decreasing the level of ecosystem services.

The Strategic Research and Innovation Agenda (SRIA) of the European Aquaculture Technology and Innovation Platform (EATiP) identified research and development (R\&D) work for the development of integrated pond aquaculture as an important part of SRIA. In spite of this, further efforts are required to get such systems accepted as important contributors to the development of sustainable European aquaculture besides other better known systems [31]. 


\section{Evolution of Integrated Agriculture-Aquaculture Systems}

\subsection{The Combination of Common Carp Farming with Plant Production}

The ability of common carp to forage for food in ponds was already recognized and exploited in Central and Eastern Europe in the early stage of pond carp farming (in the late 1800s). The species was known to consume insects and their larvae, water fleas and plant seeds alike.

Accordingly, attempts were made to increase the quantity of these organisms (the so-called "natural food") in ponds in order to guarantee that the (very low, 150-200 kg/ha) yields considered acceptable at that time would be achieved. More food organisms were observed to occur in freshly flooded areas, and thus, the production was organized on the same principles as land-based crop rotation. Fishponds were constructed on low-quality soils suited only for grazing and hay production. Meadows were flooded after some years of use in order to produce fish for some period of time. In other places, flooding took place after the first reaping of grass and the fish culture phase lasted from late spring to autumn. As the fish stocking density was extremely low, the stocked fish grew well even without feeding [32].

The first-successful—attempts to introduce fish-cum-rice production in Hungary were made in the same period in the early 1900 . Fish yields of $50-200 \mathrm{~kg} /$ ha were achieved on a rice production area of 250 ha after stocking them with yearlings [33].

\subsection{The Early Stage of Complementary Feeding-Based Common Carp Farming and Its Integration with Animal Husbandry}

The first pond farms that can be considered to be of a modern type were established in Hungary in the first decade of the twentieth century. The size of the fish farm area was already almost 8000 ha by 1924 [34]. Production was initially based on the pond's natural food organisms here, too, but feeding also started using agricultural wastes in this period. In order to increase the natural food organism producing capacity of the ponds, the pond bottom was manured, similarly to arable lands [35]. At the same time, the fish stocking density was also increased in order to utilize the natural food in the best way.

Simultaneously with the development of intensive pig farming, mainly on Western Hungarian farms and estates, fish ponds were established near pig farms and the effluents of the farm, as well as a part of the manure, were released into the fish ponds. Such a combination of pig farming and fish production was widely practiced.

\subsection{The Development of Large-Scale Integrated Fish, Crop and Livestock Production Technologies}

The development of scientifically based high-yield integrated fish production technologies in Hungary started in the 1950s. The most widespread of these were the fish-cum-rice [34], fish-cum-duck [36] and fish-cum-pig [37] integration models, but integrated systems were also used for soil amelioration and increasing soil productivity (this was the so-called "rotational use of fish ponds") [38,39]. Some of these technologies are still used today (e.g., the fish-cum-rice integration in organic rice production) but due to the changing market conditions in Europe, the technology of fish-cum-duck integration can now only be recommended for other regions (Asia and Africa) [40]. Direct integration of fish and pig farming is not used, either, because of the technological changes in large-scale livestock farming and manure disposal. Aquaculture rotation is also not used under current economic conditions, and also as consequence of the development of pond reconstruction technologies. On the other hand, new practices are being developed, including the combination of intensive fish farming with wetlands [41] or combined intensive-extensive systems [42-44]. The integration technology of intensive fish farming and energy plant production is under development, too, and aquaponics is also used in small-scale production. 


\subsubsection{Fish Production on Rice Paddies}

Rice paddies were established in East and South-East Hungary, where the number of daylight hours was the highest, with established irrigation systems allowing the paddies to be flooded and water coverage to be maintained for 100-140 days.

The technical background of fish-cum-rice production was similar to the practices applied in Asian countries: a trench system allowing easy harvesting of fish was established on the rice paddies. Technical innovations consisted of flooding and draining the paddies through a screen system. In addition, spawning, nursing, storage and wintering ponds were established, specifically with the purpose of supporting fish-cum-rice production. Spawning did not take place on the rice paddies, as their plant cover was insufficient in the spawning period, resulting in a very low egg survival [33,34].

The main fish involved in the system was domesticated common carp (Cyprinus carpio), which contributed to the pest control of rice and had a significant yield: the quantity of fish harvested on rice paddies-without feeding - was up to $50-150 \mathrm{~kg} / \mathrm{ha}$. The production goals were partly seed rearing, and partly table fish production. Feeding larvae or nursed fry were stocked for seed production. Their survival rates were about $15 \%$, and about $25-30 \%$, respectively. If the target size of fish seed was 10-30 g, the stocking density per hectare was 40,000-50,000 larvae or 15,000-25,000 "cucumber seed size" nursed fry, or 10,000-12,000 "pumpkinseed-size" nursed fry [45]. For table fish production, 100-150 g carp were stocked in the ponds at a stocking density of 150-200 ind./ha. These fish subsequently reached an individual weight of $1.0-1.5 \mathrm{~kg}$ at survival rates of $60-70 \%$. Fish larvae and small nursed fry could be stocked immediately after flooding. If the objective was table fish production, i.e., larger fish were stocked, the stocking took place after the rice took root.

The fish generally stayed among the rice, in nutrient-rich, shady areas. Massive migration to the open trenches - where the water was too warm because of the lack of a shade-providing plant cover and where birds could easily see the fish-occurred only during the draining of the paddies. Losses to smaller fish were caused by aquatic insects, frogs and smaller aquatic birds (marsh terns and gulls), while bigger fish were mainly preyed upon by night herons and grey herons. The unused surface of rice paddies, occupied partly by bunds, and partly by trenches for the fish, made up about $10 \%$ of the total area. If the farms were situated close to each other, a qualified fishing master and a fisherman were employed for an area of 200 ha. The method of fish-cum-rice production is still practiced in Hungary during organic (chemical-free) rice growing [40]. Rice paddy preparation is done with laser-controlled machines in order to ensure a bottom slightly sloping toward the outlet. Trenches deeper than usual $(30 \mathrm{~cm})$ and bottom drains are constructed so that this ditch system slopes towards the outlet (Figure 1).

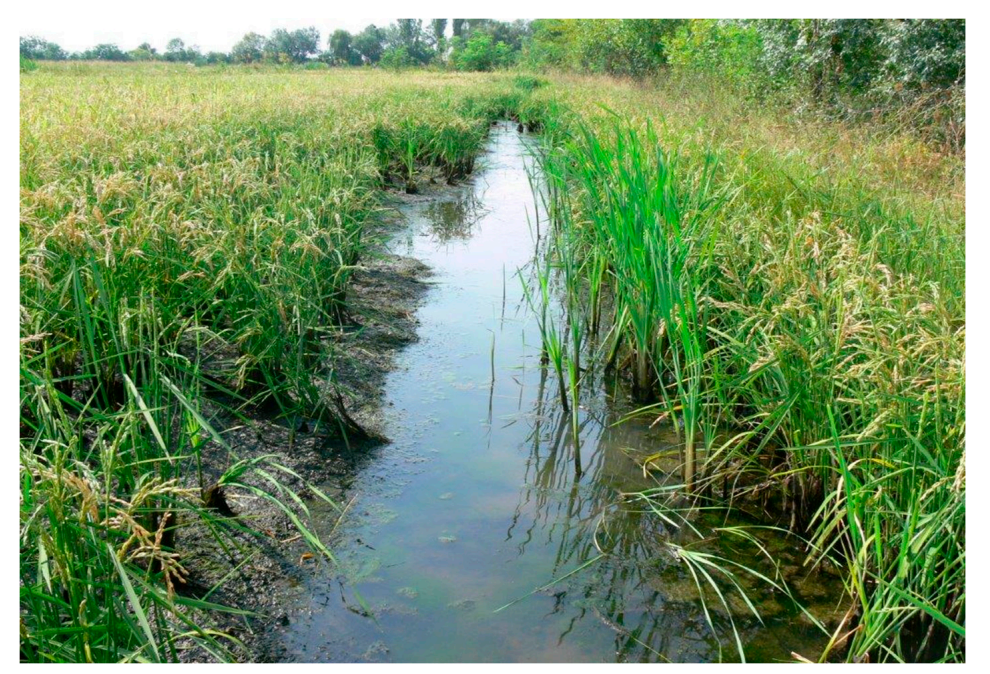

Figure 1. Organic rice production is assisted by fish stocking in rice paddies in Hungary. 
A catch basin is constructed in front of the outlet, at the deepest part of the area. Ponds are stocked in June with large nursed fry at a density of $2500 \mathrm{ind}$./ ha (2000 ind./ha of common carp and 500 ind./ha of catfish). Harvesting is done in late August. Fish survival is $30-40 \%$, the weight at harvest is $90-140 \mathrm{~g}$. The good survival rate is due to the fact that the ditches and the catch basin are protected from birds by netting. While there are no accurate measurements on the rice yield-increasing effect of fish, the density of rice pests was observed to be lower in combined systems (Figure 1).

Rice-fish-farming has declined in Hungary recently-and just a single rice farm uses fish for pest control to produce rice labeled as organic since pesticides are not used.

\subsubsection{Duck Production on Fish Ponds}

Demand for duck meat increased in Europe in the 1950s. Eastern European countries started intensive production due to the increasing demand of their domestic and foreign markets. However, neither their breeds nor the ground rearing method used at the time were sufficiently productive. In Hungary, fish-cum-duck production was introduced based on Asian examples, with a simultaneous shift to new cultured breeds $[36,46]$. Hungary imported the Pekin meat duck, and the country's production was based on this breed and its hybrids. Pond-based rearing was favorable for duck production with this method because the ducks did not become too fatty, they could keep their feathers clean and they had a rich supply of live (animal) food to make their diet complete. In addition, the infrastructure required for mass production was cheaper in such systems than in ground farming.

Fish-cum-duck integration resulted in significant advantages for fish culture, too. It became widely known by the 1960s that regular organic manure application in small dosages is favorable for common carp yields. However, the introduction of regular manuring was difficult at farms where the surface of individual ponds ranged between 50 and 200 ha and the total area was just several hundred or even several thousand hectares. In addition, the technical conditions for daily manuring were lacking at the time, too. Ducks spreading out over the surface (on smaller ponds), or flocks following each other, were kept in different areas (on larger ponds) and they continuously manured the water while moving over the ponds, like live manuring machines. (One duck produces $6 \mathrm{~kg}$ manure during its lifetime. One hundred kilograms of manure contribute to a 4 to $6 \mathrm{~kg}$ increase in the fish yield if the other technological conditions for production are appropriate.) The advantages of keeping ducks became even more obvious after the introduction of herbivorous fishes, as regular manuring significantly increased the production of planktonic organisms, the main food of silver (Hypophthalmichthys molitrix) and bighead carp (Hypophthalmichthys nobilis). Ducks also improved the pond conditions by keeping aquatic plants under control.

In case of the Pekin meat duck breed used in Hungary, about 48 to 50-day-old ducks (with a selling weight of $2.5 \mathrm{~kg}$ ) could be reared per year per female. Ducks were hatched in large incubators capable of holding 7000 to 40,000 eggs. After drying off, the hatched ducklings were placed in nursing houses. The nursing took place in special sheds where the ducklings were first kept on $1 \mathrm{~m}$ high, wire-mesh tables without contact with the humid litter. In the first stage of rearing (days 1-7, the so-called "warm rearing"), the temperature gradually decreased from $31^{\circ} \mathrm{C}$ to $18-20^{\circ} \mathrm{C}$. The feathering and intensive development of the oil gland of ducklings were accelerated by humidifying. In the second week, the ducks were driven to the "cool rearing" unit equipped with an outdoor run. The starter feed used in this period contained 16\% protein. By the end of the second week, the ducks' weight reached 350-450 g. Thereafter, the young ducks were moved to the so-called "training pond" where they got used to extensive rearing conditions. By the end of the third week, their weight was about $800 \mathrm{~g}$. The ducks were then transported to their final habitat, i.e., the fishponds. They were kept either on special duck islands situated in large ponds at some distance from the banks, or on the banks and dykes at a density of 10 ducks $/ \mathrm{m}^{2}$. Self-feeders were located on the banks or often above the water, calculating 1 feeder for 200 ducks (Figure 2). 


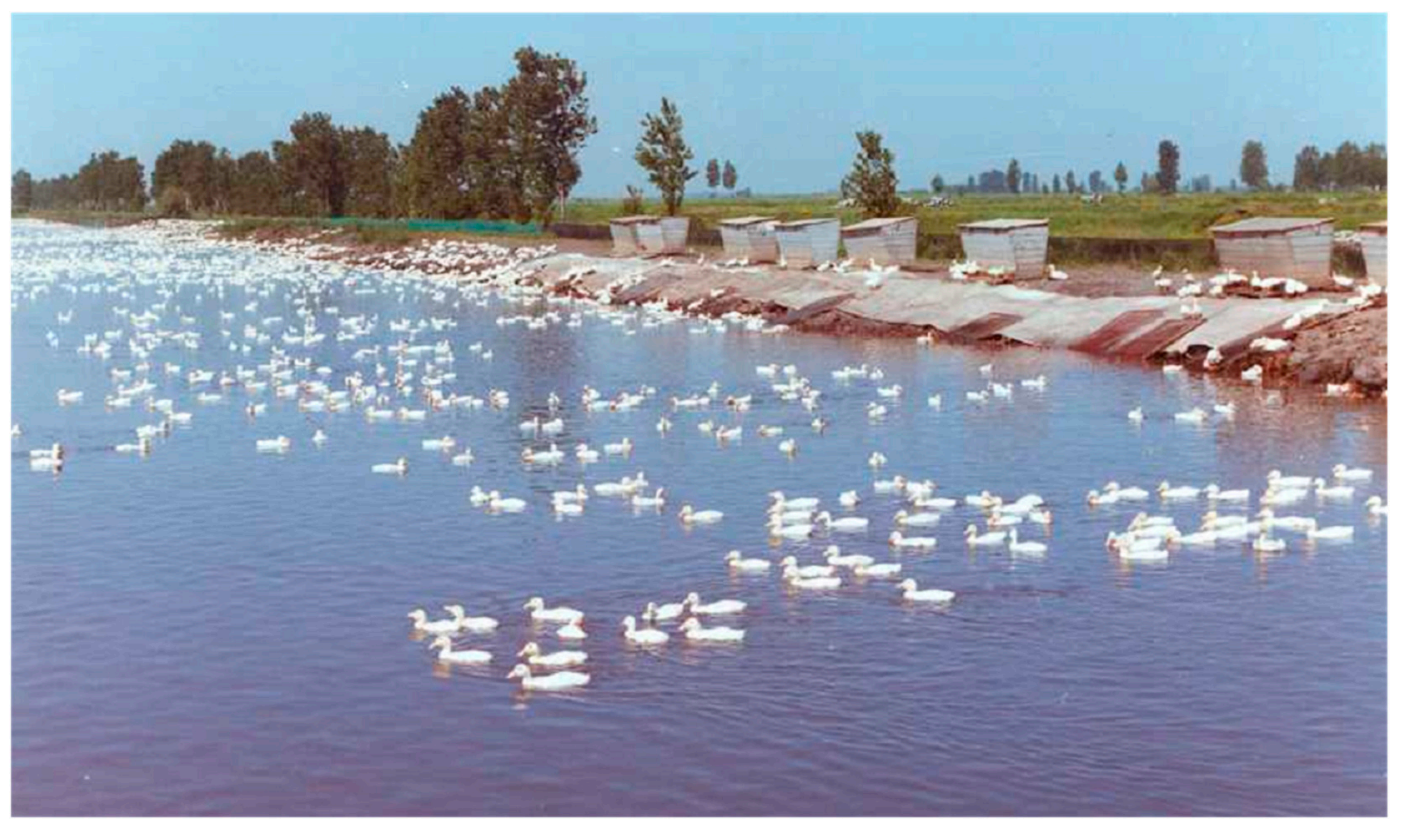

Figure 2. Large-scale duck raising on fish ponds.

Feeding above the surface of the water had the advantage that fish could utilize the spilled feed. If ducks were kept on the dykes of embankment ponds, their footfall quickly damaged the dykes. In order to avoid this damage, the dyke sections where ducks were kept were frequently rotated or protected by covering the soil with plastic nets. The most favorable option was keeping the ducks on the shores of barrage ponds.

On one hectare of fishpond 180-200 ducks were stocked at a time, taking into consideration the carrying capacity. Higher densities either caused immediate water quality deterioration and fish health problems, or meant that the extreme accumulation of organic matter in the ponds became an obstacle to fish production in the long run. In Hungarian conditions, four such groups could be reared annually, and thus a duck meat production of $1200-1400 \mathrm{~kg} /$ ha could be reached with a feed conversation rate (FCR) of 3.2-3.5. The feather production was about $150 \mathrm{~g} / \mathrm{bird}$. In the case of moderate stocking densities, the net fish yield was one tonne in ponds with common carp monoculture and around two tonnes in polyculture ponds. Only a half of this yield was due to feeding, the other half was the so-called "natural yield" coming from the consumption of food organisms developing in the ponds. The technology has not been in use for the last 20 years due to the modernization of intensive duck production systems.

\subsubsection{Integration of Pig Rearing and Fish Culture}

Fish-cum-pig integration was an established practice in Hungary, which was more often employed by medium-scale farmers as early as the 1930s. While searching for a solution for the disposal of pig manure produced in large-scale pig-fattening farms built after World War II, the Ministry of Agriculture, based on previous experience, requested the Research Institute for Fish Physiology and Wastewater Purification to develop a method allowing the use of manure in fishponds to increase their fish yield. Within the institute, this project was studied by [47]. During his experiments and the large-scale tests based on them, the technology of integrated production was developed. According to the method developed, manuring should be done on a daily basis using 50-90 kg/ha pig manure, generally produced by about 15-25 pigs. The manuring period lasts from mid-April to mid-August. If, in addition to manuring, the stocking densities (about 1800-2000 common carp of 180-200 $\mathrm{g}=360-380 \mathrm{~kg} / \mathrm{ha}$ in the case of monoculture) and the feeding were also adequate, yields of about 2.2 tonnes could be 
reached [37]. In ponds manured this way, i.e., regularly with small doses, the so-called "natural" yield was always high, reaching up to $40 \%$ of the high total fish yield.

In contrast with the method applied in small tropical ponds, pigs were not kept directly on the pond bank, as manure getting into the water and accumulating on the bottom caused local pollution. The method developed for large ponds required moving the manure to the pond bank daily, from where it was spread evenly over the pond surface. This work was first done from human-powered boats, spreading the liquid manure with shovels. Later, it was partly mechanized, spreading the pig manure from the boat using pumps. Manuring boats were also used at the point where the manure was washed out by the water current. Manuring was always done in the morning hours so that the oxygen production by algae compensated the oxygen consumption of the bacterial activity. Because of production biological reasons, the pig manure was occasionally mixed with $\mathrm{N}$ and $\mathrm{P}$ fertilizers and lime before distribution. As fewer and fewer people were willing to move the pig manure, a mechanized method of manure distribution had to be developed. On a large scale, the liquid manure was spread over the fish ponds using sprinklers attached to a tube system (1-2 sprinkler/ha) [48]. Studies on large ponds showed that the yield was the highest if $1000 \mathrm{~m}^{3} / \mathrm{ha}$ /season of liquid manure was applied. If the applied manure quantities were lower or higher, fish yields became smaller.

During the development of the pig-manure-based technology, the researchers and practical experts involved in the project gained much knowledge not directly related to the specific task concerned; later on, this knowledge significantly contributed to the development of other fish production technologies. It was observed that the oxygen level was more stable in fish ponds manured constantly with small doses, i.e., there was no oxygen shortage at dawn. Studies of the plankton showed that the zooplankton stock of regularly manured fish ponds was much more productive: young specimens dominated in the stock and the plankton populations did not collapse because of overpopulation.

These results highlighted and supported the opinion that the "natural" yield, i.e., the yield from the consumption of planktonic and other organisms is not a constant value typical of the area or the pond, but depends on the technology employed. Recognizing this fact, the fish stocking densities were increased. This higher number of fish used more of the productive, non-stagnating planktonic biomass, which resulted in an increase in the natural yield. Feeding with energy-rich grain was adjusted to the increased protein consumption. This production technology resulted in significant increases in the yield, reaching up to several hundred kilograms per hectare [49].

The technology introduced had also favorable effects on the market supply/fish consumption. Fish grew faster by the consumption of large quantities of natural food and a proportion of the stock already reached the market size in summer. With this method the marketing of the market-size fish generated income outside of the main harvesting periods (Christmas and Easter), while the partial harvesting also improved the growth and feed conversion of the remaining stock. It must be noted that pig-manure-based fish rearing technology is not used in Hungary any more due to the strict legislation on manure management, especially on pig slurry.

\subsubsection{Rotational Use of Fish Ponds}

One of the priority objectives of twentieth-century fisheries development was to utilize some of the hundreds of thousands of hectares of saline areas situated in Eastern Hungary for pond fish production [35]. This was one of the reasons why the first experimental fish farm was established in such a saline area, on the territory of the present area at Szarvas. As the fish yields were initially low on the nutrient-deficient soils of saline land, attempts were made to increase the nutrient content of the pond soils. Increasing the profit per unit area was another important goal. In order to meet this double target, the "aquaculture rotation", a three-stage technology of land use was developed. In the first stage, ducks were kept for 3 to 5 years on the fishponds constructed on low-quality soils in order to accumulate organic matter in the soil. In the second stage, legumes were grown on the area (for 2 years) further increasing the $\mathrm{N}$ content of the soil. In the third stage, rice was produced (for 3 years), using (and using up) the nutrient content of the soil [39]. 
In the fish production stage, the technology of fish-cum-duck integration was applied. Fish yields were 1.4-1.5 $\mathrm{t} / \mathrm{ha}$ of common carp in monoculture, or about $2 \mathrm{t} / \mathrm{ha}$ in polyculture. During the second stage, a mix of alfalfa and red clover provided the highest yields, achieving yields of up to $75-78 \mathrm{t} / \mathrm{ha}$ (weight of green mass) and 15-16 $t /$ ha for hay. Irrigated farming increased the yield by a further $30 \%$. In the third production stage there was no need for fertilization in the first year of rice production in spite of the fact that 1 tonne of rice removes $25 \mathrm{~kg} \mathrm{~N}, 13 \mathrm{~kg} \mathrm{P}$ and $32 \mathrm{~kg} \mathrm{~K}$ from the soil. In the second year, $70 \mathrm{~kg} / \mathrm{ha} \mathrm{N}$ and $35 \mathrm{~kg} / \mathrm{ha} P$ fertilizers were used in order to maintain the production level (4 t/ha). In the third production year, $100 \mathrm{~kg} \mathrm{~N}$ and $70 \mathrm{~kg} P$ had to be supplemented to the soil. The method is currently not in use due to the changing price relationship between fish and alfalfa/red clover in favor of fish, and the different rice production technology.

\section{Modern Pond-Based IMTA Systems: Case Studies of Increasing Production Value}

Hungary already has some multitrophic integrated fish production systems based on the latest research results and the possibilities offered by modern techniques and technologies, which incorporate the advantages of traditional pond fish farming and intensive fish culture. The basic principle of these systems is the appropriate combination of intensive and extensive aquaculture and the different activities related to the same fish pond. The number of systems employing this combination is increasing and boosts sustainable intensification. Intensive research is being carried out on the development of freshwater IMTA systems based on cooperation between different Hungarian research centers and innovative fish farms.

\subsection{The Combination of an Intensive Fish Rearing System and a Wetland}

The utilization of easily accessible geothermal water resources is primarily what provides the basis for intensive fish production in Hungary. By using thermal water from relatively low-depth wells, optimum temperatures for the target fish species can be maintained regardless of the season, and production of tropical species (e.g., tilapia [Oreochromis spp.] and African catfish [Clarias gariepinus]) also becomes possible [50]. The integration of intensive fish producing systems with extensive ponds or wetlands was made necessary by the need for the safe and non-polluting disposal of the used thermal water. Nutrient-rich water from the intensive fish rearing system, which is generally warmer than that of the recipient, can be treated in extensive fish ponds or an adequately sized constructed wetland. After such treatment, the effluent water of intensive farms can be safely released into the natural environment without significantly increasing its organic matter, phosphorus and heat load [41,42,44]. The main product of the combined system is the fish produced in the intensive system, but the use of the attached extensive system allows the production of other aquatic animals and plants as well. The animals reared in extensive systems are mostly filter feeding organisms good at utilizing the waste nutrients leaving the intensive systems, e.g., common carp, Chinese herbivorous fishes, tilapia or freshwater mussels. In the last treatment stage of effluent water, plant nutrients still remaining in the water are removed by different plants grown in the constructed wetland (e.g., reed [Phragmites communis], cattail [Typha latifolia], willow [Salix spp.]). Larger wetlands provide a habitat for wild plant and animal species, too, and consequently this special freshwater IMTA system provides considerable ecological services, as well.

A good example of the combination of an intensive fish rearing farm with an extensive pond system/wetland is the African catfish farm of Szarvas-Fish Ltd. (Szarvas, Hungary) in Tuka, whose scheme is shown in Figure 3.

The main elements of the system and the principal characteristics of their operation can be summarized as follows. 


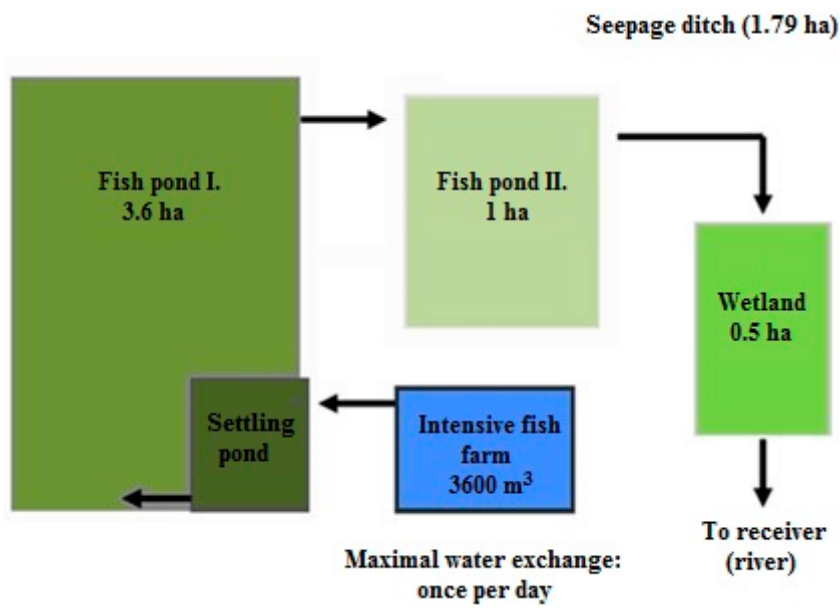

Figure 3. Schematic outline of the combined intensive-extensive fish production system of Szarvas-Fish Ltd. in Tuka [43].

\subsubsection{Intensive Fish Farm}

The total tank volume of the intensive unit is $3600 \mathrm{~m}^{3}$, where African catfish (a hybrid of Clarias gariepinus and Heterobranchus bidorsalis) are reared at high stocking densities $\left(300 \mathrm{~kg} / \mathrm{m}^{3}\right)$ in thermal water from wells. The annual production of the intensive system is about 1000 tonnes.

\subsubsection{Extensive Fishpond}

The effluent water of the intensive fish farm, after sedimentation, flows into a 3.6 ha extensive fishpond, then to a serially connected extensive fishpond with a surface area of 1 ha, where common carp and Chinese herbivorous fishes are reared without supplementary feeding. The fish yield of the extensive ponds $(2-3 t / h a)$ is a value added to the intensive production.

\subsubsection{Wetland}

The water flows from the fishponds to a 0.5 ha wetland, where the remaining nutrients are removed by artificially planted reed and cattail, which also assist the sedimentation of the suspended solids. The main function of the extensive fishpond and the constructed wetland is to reduce the organic matter content of the effluent water to levels that meet the requirements for waters to be released into natural recipients. Table 1 presents the efficiency of water treatment in extensive fish ponds and wetlands. In addition, the wetland is large enough to provide a habitat for wild animals, in particular, birds (e.g., mallard [Anas platyrhynchos]). The reed (Phragmites australis) and cattail (Typha) harvestable from the wetland provide additional income for the farm.

Table 1. Nutrient removal by the water treatment system operated at the Tuka farm of Szarvas-fish Ltd.

\begin{tabular}{cccc}
\hline Water Quality Parameters & Limit Value (mg/L) & Outflow from Farm (mg/L) & Outflow from Wetland (mg/L) \\
\hline Biological Oxygen Demand (BOD) & 50 & $25-34$ & $27-66$ \\
Total N & 55 & $20.4-23.2$ & $10.5-13.2$ \\
Total P & 10 & $1.9-2.2$ & $1.4-1.7$ \\
Total Suspended Solids (TSS) & 200 & $48-116$ & $14-28$ \\
\hline
\end{tabular}

The quality of the water released can be adjusted to the requirements by adequate sizing of the wetland. Detailed studies of the African catfish rearing system in Szarvas (Figure 4) and the attached 4-pond wetland showed that an area of 4 ha was required for the treatment of the effluents from an African fish farm with a capacity of $300 \mathrm{t} /$ year, including 3 ha of fishponds and 1 ha of wetland planted with reed and Typha species. Stocking of the fish ponds with $0.8-1.5 \mathrm{t} / \mathrm{ha}$ fish (65\% silver carp, 
$30 \%$ common carp, $5 \%$ grass carp) is recommended. Fish yields of $2-3 t /$ ha can be achieved on the ponds without feeding.

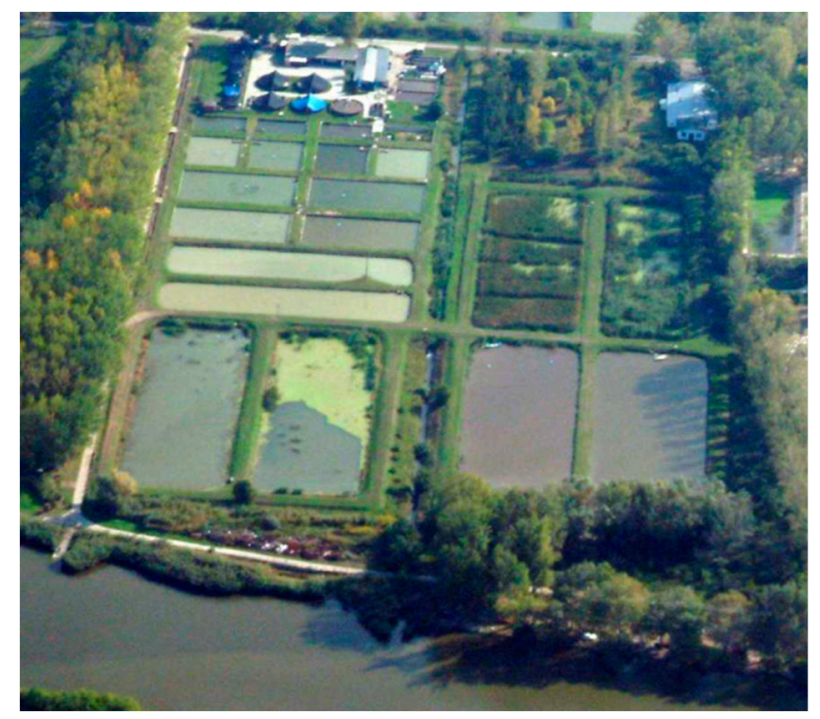

Figure 4. Combination of an intensive fish farm with extensive ponds and wetland (the intensive farm can be seen on the top, the water treatment unit consisting of two 0.5 ha fish ponds and two 0.5 ha wetlands are in the center). (Photo by courtesy of HAKI).

The combined system can process $450 \mathrm{~kg} / \mathrm{ha}$ nitrogen, $200 \mathrm{~kg} / \mathrm{ha}$ phosphorus and $1850 \mathrm{~kg} / \mathrm{ha}$ suspended organic matter. The removal ratio of the Total Ammonia Nitrogen (TAN) reaches 97\%. The removal ratio of the total $\mathrm{N}$ is $82 \%$ and of the total $\mathrm{P} 80 \%$, and the quantity of suspended organic matter is reduced by $80 \%$ [41].

The following specific tasks must be still carried out in order to further improve the system and optimize its operation:

- More accurate regulation of the nutrient flows and compensation of the reduced nutrient retention of the wetland in winter.

- Exploring the utilization possibilities of the biomass produced in the wetland.

- Increasing the diversity of aquatic organisms reared in the extensive system in order to improve the nutrient retention efficiency and diversify the utilizable products.

- Modifying the regulations limiting the operation of new aquaculture systems that significantly differ from traditional ones.

Currently, there are three intensive fish farms in operation in Hungary passing the effluent first through a fish pond and subsequently through wetland. These fish farms produce some 2400 tons of African catfish annually.

\subsection{Pond Water Recirculation}

In the context of efforts to develop the sustainable intensification of agriculture, a fish rearing system consisting of two units, i.e., intensive and extensive fish ponds, was developed (Figure 5). In the intensive unit, fish species more valuable than cyprinids are reared at high stocking densities on compound 1 feeds with high protein content. The purpose of the extensive pond, in addition to fish production, is to biologically treat the effluent water of the intensive unit with the help of its biological community. The ecological and recreational services of the extensive unit are also important. The optimal ratio of intensive to extensive ponds is 1 to $15-18$. The production of the intensive system is about $10 \mathrm{t} / \mathrm{ha}$, while the fish production of the extensive unit is $1.2-1.5 \mathrm{t} / \mathrm{ha}[42,51,52]$. 
There is a continuous water flow between the intensive and extensive parts, resulting in a strong water exchange in the intensive unit, which has a significantly lower volume. The water current transports the metabolites from the intensive ponds to the extensive one, where it is utilized through the food chain as organic manure, increasing the fish yield. At the same time, the flowing water provides oxygen to the fish kept at high densities in the intensive ponds, distributes the metabolites and other washed-out suspended solids, and also impedes stratification of water in the large pond. Water is generally circulated using low-head and high-discharge fan pumps. In the extensive unit-which is basically a polyculture fish pond-the biological community processes the metabolites produced in the intensive system, and the treated water can be partly or completely returned to the intensive unit or can be released into the natural environment (generally a surface watercourse) as a recipient. In addition to the type of intensive/extensive systems described above, there are also technical solutions where the intensive unit is placed directly in the water of the extensive pond, as shown in Figure 6. This technical solution is especially suitable for safe seed production in areas where rearing in large ponds is not feasible because of the abundance of fish-eating aquatic birds.

The commercial application of recirculation pond technology on the increase nowadays, and currently three intensive fish farms in Hungary produce European catfish and African catfish.

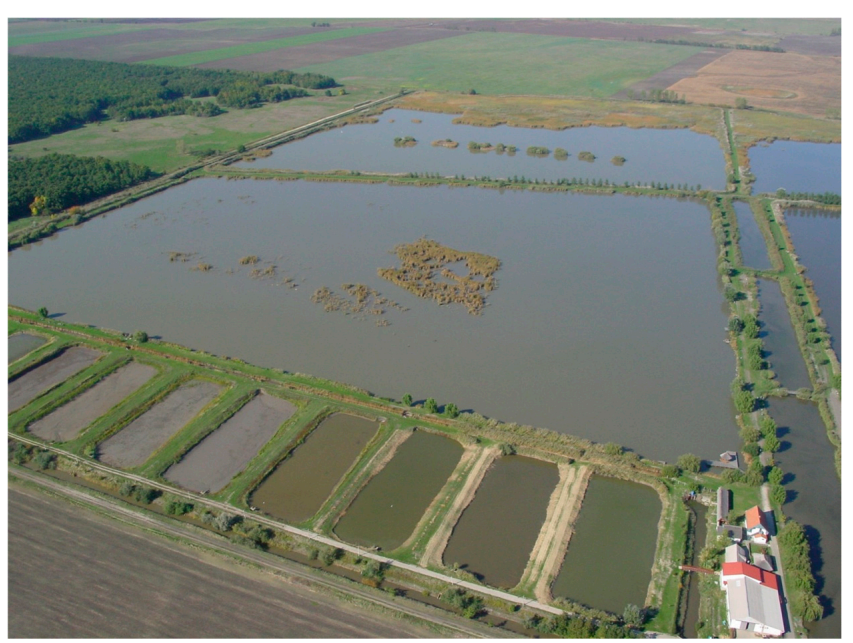

Figure 5. View of the pond recirculation system of Jászkiséri Halas Ltd. (Jászkisér, Hungary).

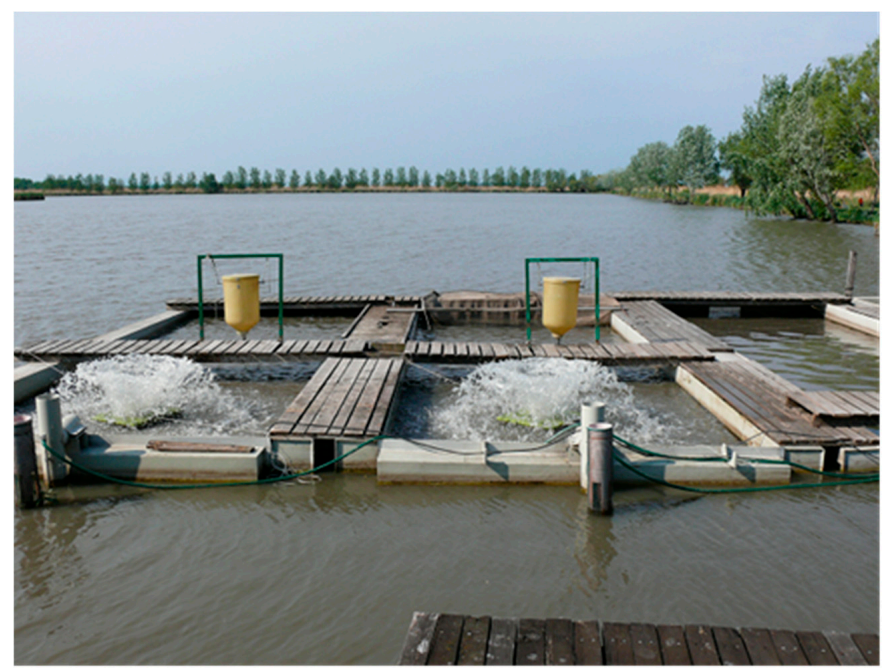

Figure 6. Intensive flow-through fish production unit installed within an extensive pond. 


\subsection{Multifunctional Pond Farming (MFPF)—Complex Use of a Wetland}

Multifunctional pond farming (MFPF) differs from traditional pond farming in that the activities performed in a multifunctional pond farm are much broader and are not limited to the production of aquatic and terrestrial organisms (animals and plants), but also include the cultivation of non-food products, as well as ecological and societal services (Figure 7). MFPF is a special type of IMTA, aiming not only at the utilization of a certain water body, but a complex wetland system. The basic component of the wetland is the fish pond; however, the system also includes the fishpond's natural and constructed environment. Practical results prove that MFPF provides a higher and more secure income to farmers through diversification and complex utilization of resources, while contributing to maintaining and increasing biodiversity, improving our knowledge of nature, as well as encouraging the social acceptance of fisheries.

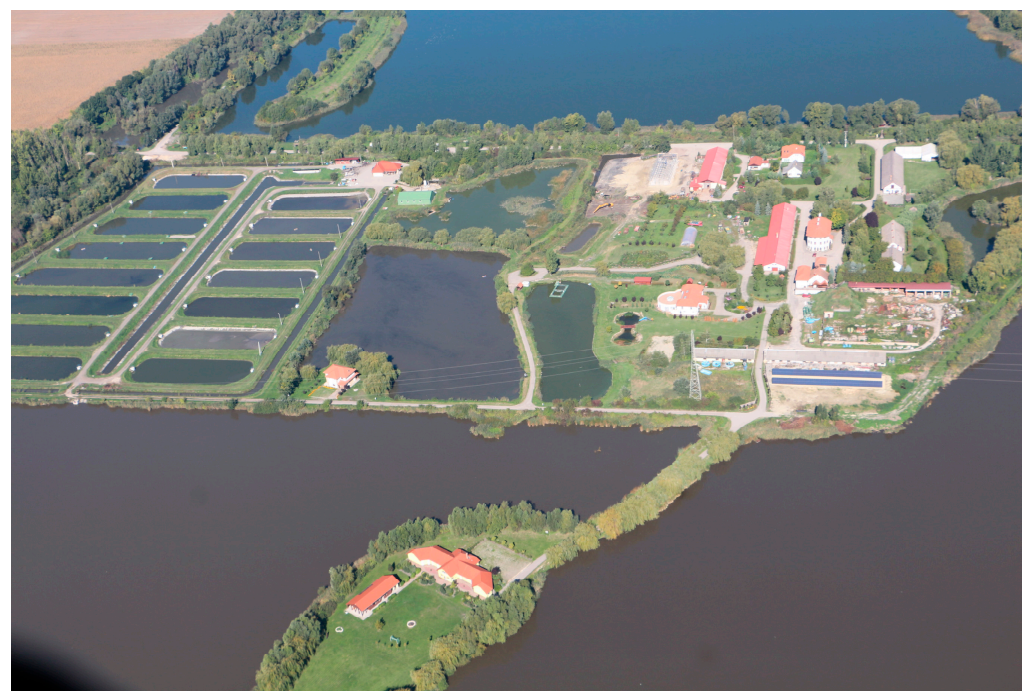

Figure 7. Schematic view of an MFPF in Hungary (by the courtesy of Aranyponty JSC. Rétimajor, Sáregres, Hungary).

The structure and operation of the pond farm of Aranyponty JSC (http:/ / www.aranyponty.hu/) is a classic example of multifunctional pond farming $[53,54]$. This private farm produces about 1600 tonnes of fish annually on 1000 ha of polyculture fish ponds using semi-intensive methods. The farm is one of the pioneers in the creation and development of MFPF, not only in Hungary but also in several European countries. The components of the MFPF system employed by Aranyponty JSC are presented in Table 2.

Table 2. Activities performed at the multifunctional pond fish farm of Aranyponty JSC.

\begin{tabular}{ll}
\hline Name of the Activity & Brief Description of the Activity \\
\hline & The main farm unit at Rétimajor with its 1000 ha fish pond area consists of \\
& 12 large ponds (10-70 ha), 16 smaller ponds (1-5 ha) and 21 over-wintering \\
ponds. The farm operates a modern fish hatchery, which produces about \\
100 million fish larvae in a propagation season lasting from February until June. \\
The total annual production of the farm is about $1600 \mathrm{t}$, of which 75 per cent is \\
common carp and 20 per cent Chinese carp (silver carp and grass carp \\
(Ctenopharyngodon idella). Other species, such as pike (Esox lucius), pike-perch \\
(Sander lucioperca), catfish (Silurus glanis), tench (Tinca tinca) and ornamental \\
fish, are also produced in smaller volumes. Organic fish farming has been \\
carried out since 2001 and, after a transition period, Aranyponty supplied \\
organic common carp and silver carp to the Hungarian market.
\end{tabular}


Table 2. Cont.

\begin{tabular}{|c|c|}
\hline Name of the Activity & Brief Description of the Activity \\
\hline Angling & $\begin{array}{l}\text { The angling industry is the main consumer of the Aranyponty Fish Farm, which } \\
\text { sells about } 70 \text { per cent of the common carp and carnivorous species produced in } \\
\text { Hungary for stocking angling waters. The farm also provides direct services to } \\
\text { anglers in its Örspuszta Anglers' Centre, where ponds of different sizes with } \\
\text { various fish species are available for recreational fishermen. The sale of fish to } \\
\text { angling waters and direct services to anglers in the Örspuszta Anglers Centre is a } \\
\text { major source of revenue for the farm. }\end{array}$ \\
\hline $\begin{array}{l}\text { Animal husbandry, } \\
\text { plant and ornamental } \\
\text { plant growing }\end{array}$ & $\begin{array}{l}\text { In addition to fish, indigenous Hungarian animal breeds (e.g., Hungarian grey } \\
\text { cattle (Bos primigenius taurus hungaricus), mangalica pigs (Sus scrofa domesticus), } \\
\text { and racka sheep (Ovis aries strepsiceros hungaricus) and vegetables and flowers } \\
\text { typical of the region are also cultivated at the farm, most of them according to } \\
\text { organic production standards. The meat and vegetables produced mainly serve } \\
\text { as raw material for the rustic cuisine of the local restaurant. }\end{array}$ \\
\hline $\begin{array}{l}\text { Ecotouristic services, } \\
\text { demonstration, } \\
\text { training programs, } \\
\text { professional events }\end{array}$ & $\begin{array}{l}\text { The farm is open to the public. An educational trail and a fishing museum allow } \\
\text { visitors to learn about fishing, fish and aquatic habitats. There are special } \\
\text { programs available for birdwatchers and nature photographers. Training and } \\
\text { demonstration programs are regularly organized for children and adults at the } \\
\text { farm. The farm's conference hall, seating } 50 \text { persons, is a popular venue for } \\
\text { domestic and international meetings. A restaurant, a wine cellar, guesthouses, } \\
\text { a small hotel and a wellness center are available to the farm's guests. }\end{array}$ \\
\hline Ecological services & $\begin{array}{l}\text { The farm is located on a RAMSAR area where } 220 \text { bird species are registered, } \\
\text { many of them protected or highly protected species, such as Ferruginous Ducks } \\
\text { (Aythya nyroca) Tufted Ducks (Aythya fuligula) and Red Crested Pochards (Netta } \\
\text { rufina) that regularly nest in the undisturbed area around the fish ponds. Besides } \\
\text { birds, numerous invertebrate species, amphibians, reptiles and mammals live in } \\
\text { the wetland area. The fish ponds also contribute to the improvement of the water- } \\
\text { and landscape management of the region. }\end{array}$ \\
\hline
\end{tabular}

The lessons learnt during the nearly 20 years of the operation of the system can be summarized as follows [55]:

- $\quad$ higher income generating ability and economic stability due to the effect of diversity, with complex utilization of natural and human resources;

- $\quad$ production of ecological and organic products as a result of environmentally friendly farming;

- $\quad$ higher employment as a result of different, mainly destination touristic services;

- improvement of the quality of wetlands and enrichment of the biodiversity in a given area through the provision of ecosystem services;

- contributing to the sustainable water management and the landscape value of the region;

- contributing to the promotion of fish, fishing and natural values, as well as to the social acceptance of fisheries;

- the efficient operation of MFPF requires a higher-level management commitment than the operation of traditional pond farms.

Further studies are needed in order to further improve the system and optimize its operation:

- characterization of the individual components of the system and their interrelations and development of a system model;

- $\quad$ valuation of the provision of ecosystem services;

- increasing the share of the use of renewable resources;

- development of fish production technologies that can be integrated into the natural environment (e.g., pond-in-pond system);

- development of locally applicable methods for the mitigation of the effects of global climate change. 
An increasing number of farms recognize and use the possibilities offered by multifunctional pond farming. The activities of Öko 2000 Ltd., Akasztó, Hungary (http:/ / www.oko2000.hu/) and Jászkiséri Halas Ltd. in this field deserve a special mention. In addition to these farms, several other fish pond farms offer angling services and/or operate as a fish restaurant as secondary activity to fish farming. It is estimated that more than 7000 tons of fish ( $50 \%$ of the total Hungarian fish pond production) is produced by fish farms with at least one additional activity besides conventional fish rearing.

\section{The Future of Integrated Aquaculture in Hungary}

Various integrated freshwater aquaculture systems have been developed and applied in Hungary over the past few decades that have contributed to the sustainable use of natural resources, mainly nutrients and water. The commercial application of these systems has also proved their environmental and social sustainability. There will be an increasing need for the use of these integrated systems in the future due to the increasing competition for finite and vulnerable freshwater resources, the expected impacts of climate change and social expectations. The new type of integrated freshwater aquaculture systems such as combined intensive-extensive systems and multifunctional fish pond systems can contribute to the sustainable use of fish ponds as valuable wetlands. The application of the integrated freshwater aquaculture systems that are the results of intensive R\&D activity and innovation can contribute to increases in production from a unit area without any deterioration in the environment and allow other activities such as ecosystem and touristic services. Besides the increase in aquaculture production, the wider use of these systems also contributes to employment in rural regions in full accordance with the objectives of the Strategic Aquaculture Plan in Hungary and that of the main objectives of the Common Fisheries Policy of the EU.

Hungarian expertise and experience, however, can also be applied in other regions where freshwater aquaculture is based on the production of aquatic animals in fish ponds, for example in Eastern European and Asian countries. The knowledge and technology transfer to Eastern Europe, where the aquaculture profile is similar to the Hungarian one, can be facilitated by the Network of Aquaculture Centers in Central and Eastern Europe (NACEE) that was established in Hungary, where its headquarters are also located. An important area of the cooperation and exchange of information among Central and Eastern European countries is to contribute to the development of integrated freshwater systems.

There has been active collaboration in freshwater aquaculture development between Hungary and China, Laos and Vietnam, but Hungary has been involved in several freshwater aquaculture development projects in the Asian region mainly through FAO expert consultancies and training programs. The flagship of the Asian collaboration was the Research Institute for Fisheries and Aquaculture (HAKI) that also established close cooperation with the Network of Aquaculture Centers of Asia Pacific (NACA). The development of integrated aquaculture systems has been a core element of almost all projects that have been implemented in Asia, also including those of a multi trophic nature, even if the term IMTA was not known and applied at that time.

Hungary should continue to play an active role in the development of collaboration between EU and non-EU Eastern European countries and also Asia. One of the promising areas of freshwater aquaculture development is the wider use of IMTA systems during the modernization of pond fish farming. Various projects and frameworks are available both in the EU and Hungary that can help the transfer of knowledge and technology related to the development and commercial application of freshwater IMTA systems. One such project is the recently started EURASTIP EU 2020 project, while in Hungary the grant program offers opportunities for new projects in developing countries. An important feature of these programs is the multi-stakeholder cooperation that, besides continued innovation, is an essential component of the development and practical application of integrated freshwater aquaculture systems.

Fish pond-based IMTA systems can be considered quasi-organic, and the common carp as the main cultured species in these systems represents an ideal candidate for organic status. Hungarian 
organic aquaculture production amounted to 3500 tonnes in 2015 and the main species cultured is common carp [56]. Although fish pond-based IMTA systems provide good basic conditions for the increase of organic aquaculture production, the potential growth is limited by the moderate market demand for organic products. The consumption of organic products (from both agriculture and aquaculture) in Hungary represents only $1 \%$ of total food consumption.

Aquaponics is the integration of aquaculture and hydroponics, a soilless system for vegetable (perhaps fish) production. [57] consider aquaponics a very promising and complex food production technology; however, the continuous monitoring of the chemical composition of the recirculating water for adequate concentrations and ratios of nutrients is needed. In addition, special attention has to be paid to the potentially toxic component, ammonium. You can find in Hungary individuals and-, families who use these systems as a hobby to produce organic vegetables for household consumption. Aquaponics is not currently part of the aquaculture sector in Hungary. In addition, there is a lack of quantitative research to support the development of economically feasible aquaponics systems.

\section{Conclusions}

The efficient use of natural resources for food production has always played an important role in Hungary, which is a small landlocked country where agriculture is an important sector, not only in food production but also in rural development. Aquaculture is a special sub-sector of the Hungarian agriculture sector, which consists mainly of pond fish farms integrated in the natural environment and the rural economy. Thus, integration of pond fish farming with other agricultural activities has a long tradition and various integrated agriculture-aquaculture systems have been developed and applied commercially for aquatic food production. Besides conventional integration, which basically means the application of organic manure in fish ponds to increase natural production, special integrated systems were also developed such as fish-cum-duck production, rotational use of fish ponds, fish and rice production. Although some of these systems and technologies have been used commonly in some tropical developing countries, mainly in Asia, the Hungarian experience in this field is in some ways unique in Europe and has provided a good basis for cooperation between Hungary and Asian developing countries. Based on existing traditions in the development of integrated aquaculture, new knowledge, the availability of modern equipment and facilities, and also national and EU financial resources, new types of integrated freshwater aquaculture systems have been developed in Hungary such as connected intensive-extensive systems, and multi-functional pond fish farms (MFPF).

It can be observed that, initially, the driving force of the development of integrated aquaculture systems was the efficient use of resources, especially nutrients and water; later, however, the protection of the natural environment, and more recently meeting social needs, have emerged as critical issues during the development of integrated freshwater systems. Although these systems provide good basic conditions for the increase of organic aquaculture production, the potential growth is limited by the moderate market demand for organic products.

It is necessary to continue innovation aimed at the development of freshwater integrated aquaculture systems. These systems are exposed to continuously changing economic conditions. With the elaboration of different technological options, the systems should be made financially less vulnerable. The adaptability of the systems to the changing climatic and weather conditions should also be increased, which requires further practice-oriented research. There are also further opportunities to include more unconventional aquatic organisms in the integrated systems (e.g., clams, crustaceans, aquatic plants) in order to improve the nutrient utilization. Moreover, further efforts are needed to investigate the application of these organisms as food for people, food for animals and also for industrial use (e.g., energy, medicines, fiber etc.).

Integration of livestock and fish, in which one or both sub-systems do not become entirely agro-industrially based, may better fit the limited resource base of small-scale farming and improve environmental sustainability. Sustainable recycling of wastes produced by industrial livestock systems 
must be attractive, both financially and environmentally and their benefits should also be understood and accepted by society.

Acknowledgments: This work was supported by EFOP3.6.3-VEKOP-16-2017-00007-“'Young researchers for talent"-Supporting careers in research activities in higher education program.

Author Contributions: Emese Békefi and Gergő Gyalog conceived and designed the experiments; András Péteri performed the experiments; Zoltán Lakner analyzed the data; József Popp and Judit Oláh contributed reagents/materials/analysis tools; and László Váradi, József Popp, Judit Oláh and Gergő Gyalog wrote the paper.

Conflicts of Interest: The authors declare no conflict of interest.

\section{References}

1. OECD/FAO. Agricultural Outlook 2017-2026, Fish and Seefood; OECD-FAO Food and Agriculture Organisation of the United Nations: Paris, France, 2017. [CrossRef]

2. OECD/FAO. Agricultural Outlook, OECD Agriculture Statistics (Database); Food and Agriculture Organisation of the United Nations: Rome, Italy, 2017. [CrossRef]

3. Godfray, H.C.J.; Beddington, J.R.; Crute, I.R.; Haddad, L.; Lawrence, D.; Muir, J.F.; Pretty, J.; Robinson, S.; Thomas, S.M.; Toulmin, C. Food security: The challenge of feeding 9 billion people. Science 2010, 327, 812-818. [CrossRef] [PubMed]

4. Little, D.; Edwards, P. Integrated Livestock-Fish Farming Systems; Food and Agriculture Organisation of the United Nations: Rome, Italy, 2003; ISBN 9251050554.

5. Edwards, P. Aquaculture for enhancing nutritional and economic improvement in Asia. In Proceedings of the Compendium of Asian-Pacific Aquaculture 2011, Annual Conference of the WAS-APC, Kochi, India, 17-20 January 2011; pp. 1-11.

6. Edwards, P. Aquaculture environment interactions: Past, present and likely future trends. Aquaculture 2015, 447, 2-14. [CrossRef]

7. Gyalog, G.; Váradi, L.; Gál, D. Is intensification a viable way for pond culture in Central and Eastern Europe? AACL Bioflux 2011, 4, 584-589.

8. Turcios, A.E.; Papenbrock, J. Sustainable treatment of aquaculture effluents-what can we learn from the past for the future? Sustainability 2014, 6, 836-856. [CrossRef]

9. Chopin, T. Progression of the integrated multi-trophic aquaculture (IMTA) concept and upscaling of IMTA systems towards commercialization. Aquac. Eur. 2011, 36, 5-12.

10. Chopin, T.; Cooper, J.A.; Reid, G.; Cross, S.; Moore, C. Open-water integrated multi-trophic aquaculture: Environmental biomitigation and economic diversification of fed aquaculture by extractive aquaculture. Rev. Aquac. 2012, 4, 209-220. [CrossRef]

11. Troell, M.; Joyce, A.; Chopin, T.; Neori, A.; Buschmann, A.H.; Fang, J.-G. Ecological engineering in aquaculture-potential for integrated multi-trophic aquaculture (IMTA) in marine offshore systems. Aquaculture 2009, 297, 1-9. [CrossRef]

12. Abreu, M.H.; Varela, D.A.; Henríquez, L.; Villarroel, A.; Yarish, C.; Sousa-Pinto, I.; Buschmann, A.H. Traditional vs. integrated multi-trophic aquaculture of Gracilaria chilensis CJ Bird, J. McLachlan \& EC Oliveira: Productivity and physiological performance. Aquaculture 2009, 293, 211-220. [CrossRef]

13. Bostock, J.; McAndrew, B.; Richards, R.; Jauncey, K.; Telfer, T.; Lorenzen, K.; Little, D.; Ross, L.; Handisyde, N.; Gatward, I. Aquaculture: Global status and trends. Philos. Trans. R. Soc. Lond. B Biol. Sci. 2010, 365, 2897-2912. [CrossRef] [PubMed]

14. Bostock, J.; Muir, J.; Young, J.; Newton, R.; Paffrath, S. Prospective Analysis of the Aquaculture Sector in the EU; European Commission, Joint Research Centre, Institute for Prospective Technological Studies: Seville, Spain, 2008.

15. Hughes, A.D.; Black, K.D. Going beyond the search for solutions: Understanding trade-offs in European integrated multi-trophic aquaculture development. Aquac. Environ. Interact. 2016, 8, 191-199. [CrossRef]

16. Barrington, K.; Chopin, T.; Robinson, S. Integrated Multi-Trophic Aquaculture (IMTA) in Marine Temperate Waters; Food and Agricultural Organisation: Rome, Italy, 2009; pp. 7-46.

17. Lance, Q.; Mu, Y.; Zhao, Z.; Lam, V.W.; Sumaila, U.R. Economic challenges to the generalization of integrated multi-trophic aquaculture: An empirical comparative study on kelp monoculture and kelp-mollusk polyculture in Weihai, China. Aquaculture 2017, 471, 130-139. [CrossRef] 
18. Naylor, R.L.; Goldburg, R.J.; Primavera, J.H.; Kautsky, N.; Beveridge, M.C.; Clay, J.; Folke, C.; Lubchenco, J.; Mooney, H.; Troell, M. Effect of aquaculture on world fish supplies. Nature 2000, 405, 1017-1024. [CrossRef] [PubMed]

19. Neori, A.; Ragg, N.L.C.; Shpigel, M. The integrated culture of seaweed, abalone, fish and clams in modular intensive land-based systems: II. Performance and nitrogen partitioning within an abalone (Haliotis tuberculata) and macroalgae culture system. Aquac. Eng. 1998, 15, 215-239. [CrossRef]

20. Neori, A.; Shpigel, M. Algae treat effluents and feed invertebrates in sustainable integrated mariculture. World Aquac. 1999, 30, 46-49.

21. Ferreira, J.; Hawkins, A.; Monteiro, P.; Moore, H.; Service, M.; Pascoe, P.; Ramos, L.; Sequeira, A. Integrated assessment of ecosystem-scale carrying capacity in shellfish growing areas. Aquaculture 2008, 275, 138-151. [CrossRef]

22. Gangnery, A.; Bacher, C.; Buestel, D. Application of a population dynamics model to the Mediterranean mussel, Mytilus galloprovincialis, reared in Thau Lagoon (France). Aquaculture 2004, 229, 289-313. [CrossRef]

23. Cromey, C.J.; Nickell, T.D.; Black, K.D. DEPOMOD-modelling the deposition and biological effects of waste solids from marine cage farms. Aquaculture 2002, 214, 211-239. [CrossRef]

24. Fabi, G.; Manoukian, S.; Spagnolo, A. Impact of an open-sea suspended mussel culture on macrobenthic community (Western Adriatic Sea). Aquaculture 2009, 289, 54-63. [CrossRef]

25. Ferreira, J.; Sequeira, A.; Hawkins, A.; Newton, A.; Nickell, T.; Pastres, R.; Forte, J.; Bodoy, A.; Bricker, S. Analysis of coastal and offshore aquaculture: Application of the FARM model to multiple systems and shellfish species. Aquaculture 2009, 289, 32-41. [CrossRef]

26. Yip, W.; Knowler, D.; Haider, W. Valuing the Willingness-to-pay for Ecosystem Service Benefits from Integrated Multi-trophic and Closed Containment Aquaculture in British Columbia. In Proceedings of the 14th Annual BIOECON Conference Resource Economics, Biodiversity Conservation and Development, Cambridge, UK, 18-20 September 2012.

27. Bakhsh, H.K.; Chopin, T. A variation on the IMTA theme: A land-based, closed-containment freshwater IMTA system for tilapia and lettuce. Aquac. Can. 2012, 22, 57-60.

28. Bakhsh, H.K.; Chopin, T.; Murray, S.; Belyea, E.; Hamer, A. Adapting the Concepts of Tropical Integrated Agriculture-Aquaculture (IAA) and Aquaponics to Temperate-Cold Freshwater Integrated Mullti-Trophic Aquaculture (FIMTA). In Aquaculture Canada 2014, Proceedings of Contributed Papers; Bulletin of the Aquaculture Association of Canada; Wade, J., Jackson, T., Brewer, K., Eds.; Aquaculture Association of Canada: St. Andrews, NB, Canada, 2015; pp. 17-25.

29. Chopin, T. Monitoring the invisible with highly visible consequences: Let's not forget the dissolved inorganic nutrients so we can use them efficiently. Bull. Aquac. Assoc. Can. 2015, 2015, 53-61.

30. Little, D.; Muir, J. A Guide to Integrated Warm Water Aquaculture; Institute of Aquaculture, University of Stirling: Stirling, Scotland, 1987; ISBN 0901636711.

31. European Aquaculture Technology and Innovation Platform (EATIP). The Future of European Aquaculture-Our Vision: A Strategic Agenda for Research \& Innovation. European Aquaculture Technology and Innovation Platform. 2012, p. 44. Available online: https://www.trafoon.org/info/98 (accessed on 5 January 2018).

32. Herman, O. Brief Summary of Fisheries; Természettudományi Társulat: Budapest, Hungary, 1988; p. 200.

33. Woynarovich, E. Common Carp Farming in Rice Paddies; Mezőgazdasági Kiadó: Budapest, Hungary, $1952 ;$ p. 55.

34. Woynarovich, E. Fish Farming in Rice Paddies Tógazdasági Haltenyésztés a Gyakorlatban; Mezőgazdasági Kiadó: Budapest, Hungary, 1954; p. 359.

35. Fischer, F. Overview of Hungarian Fisheries, Their Role and Future in Agricultural Production and Water Management; Földmúvelésügyi Minisztérium: Budapest, Hungary, 1931; p. 222.

36. Balogh, L.; Kozma, L.; Mosonyi, G. Broiler Ducks on Fish Ponds; Mezőgazdasági Kiadó: Budapest, Hungary, 1975; p. 210.

37. Woynarovich, E.; Zámbó, I. Organization and Results of Fish Meat Production at the Bikal State Farm; Mezőgazdasági Kiadó: Budapest, Hungary, 1963; p. 88.

38. Fábry, G. Chemical Study of the Soils Treated with the Szarvas Aquaculture Rotation Method. A Halhústermelés Fejlesztése; Haltenyésztési Kutatóintézet: Szarvas, Hungary, 1975; p. 91.

39. Müller, F. Economic Efficiency of the Utilization of Saline Soils Using Aquaculture Rotation; Haltenyésztési Kutatóintézet: Szarvas, Hungary, 1975; p. 79. 
40. Jancsó, M.; Gyalog, G.; Izsó, L.; Nagy, G.; Váradi, L.; Rónyai, A. Fish Culture in Organic Rice Fields, Proceedings of the 33rd Scientific Conference on Fisheries and Aquaculture; HAKI, Fisheries and Aquaculture Development: Szarvas, Hungary, 2009; pp. 115-122. (In Hungarian)

41. Kerepeczki, E. Treatment of Intensive Fish Farm Effluents in Constructed Wetland Systems; University of Debrecen: Debrecen, Hungary, 2006.

42. Gál, D. Development of Environment-Friendly Combined Pond Fish Production Systems; University of Debrecen, Faculty of Animal Breeding: Debrecen, Hungary, 2006.

43. Váradi, L.; Min, K. The development of freshwater integrated multi-trophic aquaculture (IMTA) systems in China and Hungary. In Proceedings of the AQUA 2012 WAS-EAS Aquaculture Conference, Prague, Czech Republic, 2012.

44. Váradi, L.; Radics, F. African Catfish Production in Geothermal Water: A Success Story in Hungary. In Proceedings of the FAO-NACEE Workshop on Current Issues and Challenges in the Marketing of Aquaculture Products, Tyumen, Russia, 26 August 2010.

45. Szalai, M. Survival rate is a decisive factor in fish rearing on rice paddies. Halászat 1954, 3, 8-9.

46. Woynarovich, E. The Feasibility of Combining Animal Husbandry with Fish Farming, with special reference to Duck and Pig Production. In Advances in Aquaculture, Proceedings of the FAO Technical Conference on Aquaculture, 26 May-2 June 1976, Kyoto, Japan; Pillay, T.V.R., Dill, W.A., Eds.; Fishing News Books Ltd.: Oxford, UK, 1979; pp. 203-208.

47. Woynarovich, E. Organic manuring of fish ponds: The carbon fertilizing method. Halászat 2005, 3, 1-12.

48. Kintzly, Á.; Oláh, J. Fishpond Utilization of Liquid Pig Manure. VI. Halászati Tudományos Tanácskozás; HAKI: Szarvas, Hungary, 1984; pp. 22-24.

49. Ruttkay, A. Fish Feeding Research in Hungary-1895-1995; HAKI Fisheries Development: Szarvas, Hungary, 2000; pp. 21-41.

50. Váradi, L. Utilization of geothermal water resources for aquaculture in Hungary. In The Role of Aquaculture in World Fisheries, Proceedings of the World Fisheries Congress; Heggberget, T.G., Ed.; Oxford \& IBH Publishing Co., Pvt. Ltd.: New Delhi, India, 1996; pp. 206-213.

51. Gál, D.; Szabó, P.; Pekár, F.; Váradi, L. Experiences on nutrient cycles during the operation of a combined intensive-extensive pond fish production system. Hidrol. Közlöny 2001, 81, 364-366.

52. Váradi, L.; Gál, D.; Pekár, F.; Szabó, P. Combined extensive-intensive pond fish production system for the sustainable use of natural resources. Hung. Agric. Res. 2001, 10, 13-15.

53. Bekefi, E.; Varadi, L. Multifunctional pond fish farms in Hungary. Aquac. Int. 2007, 15, 227-233. [CrossRef]

54. Lévai, F.; Váradi, L. The development of a multifunctional pond fish farm in collaboration with a research institute. In Proceedings of the EIFAC Symposium on Aquaculture Development-Partnership between Science and Producers Associations, Wierzba, Poland, 26-29 May 2006; EIFAC Occasional Paper No. 37; FAO: Rome, Italy, 2006; pp. 83-86.

55. Levai, F. Back to the Future in Aquaculture, Conference Common Fisheries Policy. Which Future for Aquaculture? European Commission: Salzburg, Austria, 2012.

56. General for Maritime Affairs and Fisheries, Director-General. The EUMOFA "EU ORGANIC AQUACULTURE"; Directorate-General for Maritime Affairs and Fisheries: Brussels, Begium, 2017; p. 48. Available online: https://sectormaritimo.es/wp-content/uploads/2017/06/Study-report_organicaquaculture.pdf (accessed on 5 January 2018).

57. Bittsanszky, A.; Uzinger, N.; Gyulai, G.; Mathis, A.; Villarroel, M.; Kotzen, B.; Komives, T. Nutrient supply of plants in aquaponic systems. Ecocycles Sci. J. Eur. Ecocycles Soc. 2016, 2, 17-20. [CrossRef]

(C) 2018 by the authors. Licensee MDPI, Basel, Switzerland. This article is an open access article distributed under the terms and conditions of the Creative Commons Attribution (CC BY) license (http://creativecommons.org/licenses/by/4.0/). 